\title{
Gascoyne River, Western Australia: alluvial aquifer, groundwater management and tools
}

\author{
L. Leonhard ${ }^{1}$, K. Burton ${ }^{1} \&$ N. Milligan ${ }^{2}$ \\ ${ }^{1}$ Department of Water, Western Australia, Australia \\ ${ }^{2}$ Cymod Systems, Perth, Western Australia, Australia
}

\begin{abstract}
The Carnarvon Horticultural Area adjacent to the Gascoyne River, Western Australia has since around 1928 grown to be the major supplier of fresh fruit and vegetables for the Perth region. Horticulture in this area is sustained by a small niche humid climatic zone within an arid environment with an annual rainfall generally less than $200 \mathrm{~mm}$ ( 8 inches). The Gascoyne River alluvial aquifer system is the sole source of "fresh" water for both the Carnarvon Horticultural Area and Carnarvon Township. This alluvial aquifer system comprises the River Bed Sand and an Older Alluvial Aquifer. Significant "fresh" groundwater is present within these alluvial aquifers, where groundwater storage is recharged only during brief restricted periods of river flow. Management of the Gascoyne River alluvial aquifer system has always been essential to ensure that the required quantity and quality of groundwater for both irrigated horticulture and town water can be sustained through extensive periods of no recharge (no flow). Groundwater management techniques have progressed from an early trial and error process referred to as the "Rules of the River" through to groundwater modelling techniques ranging from spreadsheets in the early 1980s to the current MODFLOW 2000. The Western Australian Department of Water has used the outputs of these processes, together with regular measurement of both groundwater level and salinity obtained from a network of observation bores, to ensure sustainability of the water supply to both the reticulated horticultural precinct and Carnarvon Township.

Keywords: Gascoyne River, alluvial aquifer, Carnarvon Horticultural Area, Western Australia Department of Water, groundwater modelling, groundwater management.
\end{abstract}




\section{Introduction}

The town of Carnarvon is in the mid-west of Western Australia (WA) just south of the Tropic of Capricorn and approximately $950 \mathrm{~km}$ (600 miles) north northwest of Perth. The town is located at the mouth of the Gascoyne River adjacent to the Indian Ocean at a latitude of $24^{\circ} 53^{\prime} 02^{\prime \prime} \mathrm{S}$ and longitude of $113^{\circ} 39^{\prime} 40^{\prime \prime} \mathrm{E}$ (Figure 1).

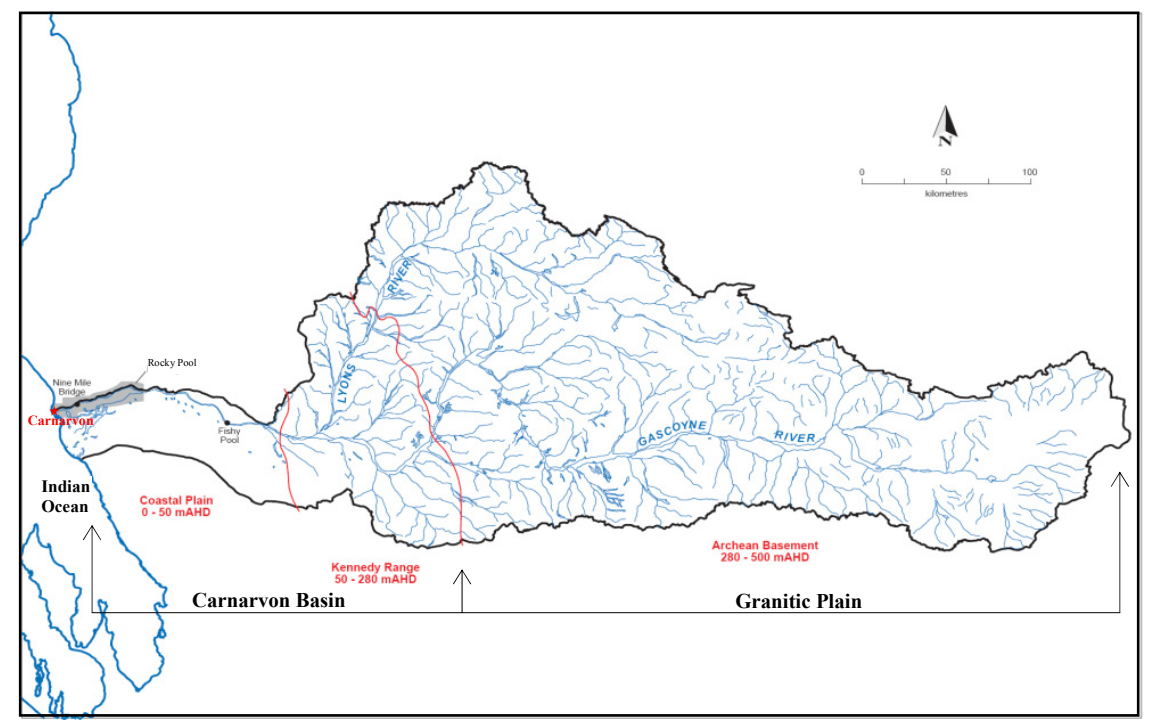

Figure 1: Gascoyne River catchment and Carnarvon groundwater management area.

The combination of a localised mild humid environment together with the availability of fresh groundwater from the Gascoyne River alluvial aquifer has supported the development of the Carnarvon Horticultural Area (CHA) as an important source of fruit and vegetables for Perth metropolitan area. The major constraining factor on horticultural production is the ephemeral nature of the Gascoyne River, where river flow is required to recharge the alluvial aquifer system. The CHA has continued to be challenged by uncertainties related to maintaining an adequate, dependable and low salinity groundwater supply from an intermittent ephemeral river system.

This paper summarizes the development of horticulture in Carnarvon area as related to the Gascoyne River alluvial aquifer system. The complexity of this alluvial system has been the basis of numerous studies and groundwater modelling exercises. Most of these studies have endeavoured to quantitatively establish the sustainable volume for groundwater abstraction in order to develop appropriate water use policies to ensure quality and quantity of the resource. 


\section{History}

Carnarvon is one of WA's most important horticultural producing areas based on the use of the groundwater from the Gascoyne River alluvial system. There are currently 1030 ha of land under horticultural production in the CHA. The gross value of the horticultural production in 2008 was $\$ 72.8$ million for 34,500 tonnes. Bananas are the highest value fruit crop; with an average yield of $43 \mathrm{t} / \mathrm{ha}$ (Hill [1]). Other crops producible in the CHA include tomatoes, capsicum, table grapes, oranges, cucumbers, melons, avocado, mandarin and pumpkins.

Horticultural activity in the Carnarvon region began with the planting of the first banana suckers in 1928 (Dodson [2]). Irrigated banana-growing was not on a large scale until after 1933 when the area was sub-divided. The irrigation water for these bananas was obtained from the Gascoyne River alluvial aquifer through unrestricted pumping of fresh groundwater from bores located within the plantation boundaries or from shallow wells located in the riverbed and banks. As the horticultural activities continued to develop and groundwater consumption steadily increased, it was observed that water in the riverbed sand was available for less time after recharge from each river flow. Growers in unfavourable locations found it necessary to obtain part or all of their water supplies from deeper bores developed in the older alluvium of the Gascoyne River. Increased groundwater production from the deeper alluvium adjacent to the river channel resulted in a lowering of the groundwater levels in many areas. This induced the lateral flow of brackish groundwater from areas further away from the river with subsequent increases in local groundwater salinity (Department of Northern Development [3]).

Drought conditions occurred over the Gascoyne River catchment in the mid 1950s and again in 1959 during an era of local expansion in the Carnarvon Horticultural Area. Excessive extraction from the older alluvium during this period resulted in saline groundwater contamination of some portions of the alluvial aquifer with subsequent abandonment of several plantations. The reduction in groundwater quality was observed to be more severe in wells and bores on the south bank of the Gascoyne River which, with the exception of those immediately adjacent to the river channel, became too saline for irrigation. Many bores furthest from the river on the northern bank were also abandoned for the same reasons (Department of Northern Development [3]).

The original town water supply for Carnarvon was until 1960 obtained from a borefield located on Water Supply Island within the Gascoyne River channel 3 kilometres north of the Carnarvon town site. Here a combination of increased groundwater production for plantations situated on the north bank of the Gascoyne River near the river mouth and groundwater abstraction for town water supply lowered groundwater levels below sea level. This induced the landward movement of a marine saline wedge and subsequent abandonment of plantations situated in the far western area of the CHA and the town water supply bores on Water Supply Island (Department of Northern Development [3]).

Declining groundwater quality during this period resulted in the WA Government assuming management of the CHA groundwater abstraction, 
gazetting it as a groundwater area in 1959. Government policies implemented included licensing of private bores and restricting groundwater production when groundwater salinity exceeded $1000 \mathrm{mg} / \mathrm{L}$ total dissolved solids (TDS). These policies combined with a succession of favourable river flow years through the 1960s prevented further deterioration of the groundwater resources across the CHA (Public Works Department [4]).

Increasing salinity of the groundwater drawn from the alluvial aquifer beneath Water Supply Island for public water supply forced the gazetting and subsequent development of groundwater resources within the Carnarvon Water Reserve (Figure 2).

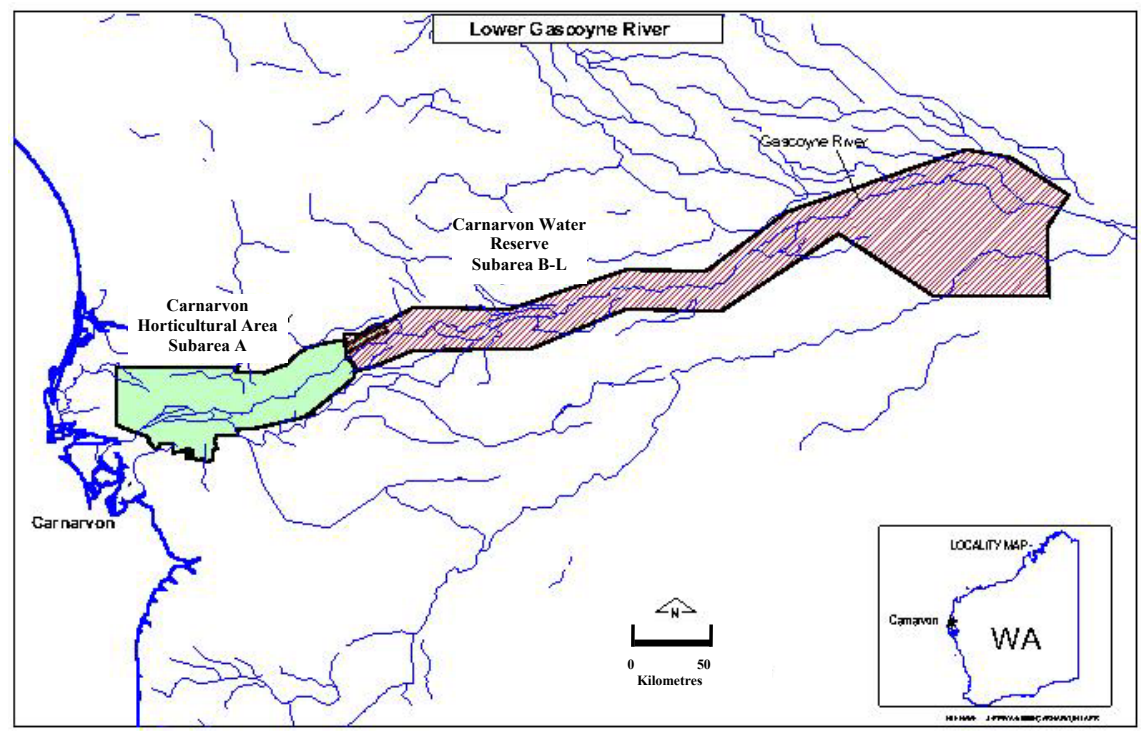

Figure 2: Lower Gascoyne River, groundwater management areas.

As a management tool, the river channel and adjacent bank was divided into eleven groundwater management units referred to as Subareas A through $\mathrm{L}$ (excluding I). Subarea A comprises the CHA from Nine Mile Bridge to the river mouth at Carnarvon. Subareas B-L make up the Carnarvon Water Reserve (CWR) located between Rocky Pool and Nine Mile Bridge.

Groundwater within the alluvial aquifer of Subarea A is abstracted for horticulture from privately constructed wells, bores and spear points. To enhance groundwater abstraction from the alluvial aquifer, plantations adjacent to the river have been allowed access to the river channel through 'prolongations' or extensions of the property line to the river channel centre point. Not all plantations have access to groundwater from Subarea A due to a number of reasons including not having access to the river through a 'prolongation', or being located in an area where the river bed sand is poorly developed across the 'prolongation' or the underlying older alluvium contains brackish groundwater. 
The CWR has been developed under license by the WA Water Corporation (WC) as the public water source for the Town of Carnarvon and as an additional water source for irrigation of the CHA. The Gascoyne Water Cooperative (GWC) has an agreement with the WC to distribute this water to the CHA.

While bananas are still an important crop, the CHA has diversified, with other fruit and vegetable production including mangoes, stone fruit, melons, avocados, tomatoes, pumpkins and more recently grapes. This horticulture, including bananas, was valued in 2009 at approximately 75 million dollars (Gascoyne Development Commission [5]).

The Gascoyne River groundwater management policy for the CHA has been challenged by an increase in groundwater demand. This demand has been driven by an expansion of the horticultural area under the WA Government's Gascoyne Foodbowl Initiative and the incorporation of new crop varieties resulting in longer growing seasons. Other issues affecting management policy include changes in plantation ownership with loss of local water management knowledge and more extreme rainfall variability affecting the extent and duration of river flow events with subsequent less dependable groundwater recharge.

\section{Previous work}

To address the CHA water supply demand issues, the WA Government has instigated a number of groundwater investigations and evaluations commencing in 1938 with the drilling of 60 exploration groundwater bores along the river, of which 35 were successful. Another 50 bores, 22 of which were successful, were constructed in 1946 (Dodson [2]).

Following the failure of the river to flow in 1954, the WA Government initiated another drilling program to evaluate groundwater resources across the Gascoyne River flood plain. This program constructed 40 bores, with only one being successful and the rest too saline for horticulture. Both the WA Geological Survey and the WA Water Authority conducted a number of groundwater resource evaluations for the Gascoyne River between 1968 and 1993. Their estimations of groundwater storage were used in early groundwater modelling for aquifer status reporting.

\section{Physiography and climate}

The Gascoyne River extends in a westerly direction from about $650 \mathrm{~km}$ inland of the Indian Ocean and occupies an elongate drainage basin with a catchment area of about $79000 \mathrm{~km}^{2}$ (Martin [6]). The river rises below the Wilgoona Hill in the Robinson Ranges west of the Gibson Desert and flows into the Indian Ocean at Carnarvon. The catchment physiography comprises two distinct areas: an inland etched, granitic plain; and the Carnarvon Basin, which includes the Kennedy Range Plateau and coastal plain (Dodson [2]).

The granite plain, with an average elevation of $400 \mathrm{~m}$ above the Australian Height Datum (AHD), is situated east of the Kennedy Range Plateau. This area is characterised by gentle slopes with broad, ill-defined flood ways within wide 
valleys interspaced with isolated peaks rising to approximately $700 \mathrm{~m}$ AHD. Rainfall over the inland granitic plain is the source for surface flow, as the flood plain lacks significant tributaries.

The Gascoyne River flood plain is situated within the coastal plain, which slopes gently to the west from the Kennedy Ranges. Downstream from Rocky Pool, the river bed falls about $0.67 \mathrm{~m} / \mathrm{km}$. Mudflats, palaeodrainages and abandoned river channels associated with former Gascoyne River processes are identifiable within the flood plain.

The climate across the Carnarvon region is classified as arid with erratic and unreliable rainfall, hot summers and mild winters. Evaporation in Carnarvon is about $2600 \mathrm{~mm} /$ annum, with most occurring during the summer period November-April. Rainfall across the Gascoyne River catchment averages between 180 and $200 \mathrm{~mm}$ ( 8 inches). River flow is predominately associated with rainfall originating from cyclones and summer thunderstorms related to atmospheric lows that penetrate beyond the Kennedy Ranges some $400 \mathrm{~km}$ inland.

\section{Gascoyne River system and hydrogeology}

The Lower Gascoyne River flows along a well-confined braided channel through quaternary alluvial terraces, resting upon early Tertiary and Mesozoic sediments of the Carnarvon Basin (Cymod [7]). It crosses the Rocky Pool Anticline at Rocky Pool, with the westward portion of the Gascoyne River channel occupying a low-sinuosity channel varying in width from about $75 \mathrm{~m}$ to $1200 \mathrm{~m}$ (Martin [6]). This anticlinal structure constrains groundwater flow, separating the alluvial aquifer system present downstream of Rocky Pool (latitude $24^{\circ} 45^{\prime} 15^{\prime \prime} \mathrm{S}$, longitude $114^{\circ} 08^{\prime} 08^{\prime \prime} \mathrm{E}$ ) from that in the Rock Pool - Fishy Pool area (Rockwater [8]).

The Gascoyne River has a great variation in runoff and duration of river flow, largely the consequence of the size of the catchment combined with erratic and fluctuating climatic conditions that deliver rainfall to the area. Groundwater is stored within the Gascoyne River flood plain sediments to a depth of $60 \mathrm{~m}$ below ground level. The key features of the sediments are:

- The Gascoyne River has a relatively stable terrace morphology that tends to maintain the river to the primary channel and overbank areas of ponding.

- The river sediment load varies in particle size from clay to gravel fractions, resulting in an alluvium of mix character. Clay and silt fractions are commonly deposited in overbank ponding areas, with the heavier sand and gravel fractions forming aggrading channel bed-loads.

- The river sediments occur as an alluvial wedge containing isolated sand sheets and channel-derived sand bodies within a matrix of sandy silt and clay.

The groundwater flow system in the saturated alluvial sediments (alluvial aquifer system) associated with the Gascoyne River floodplain is unconfined to semi-confined, heterogeneous and anisotropic (Figure 3). The base of the alluvial 
aquifer system is formed by the relatively impermeable Cretaceous Toolonga Calcilutite or (the equally impermeable) Tertiary Cardabia Calcarenite (Martin [6]).

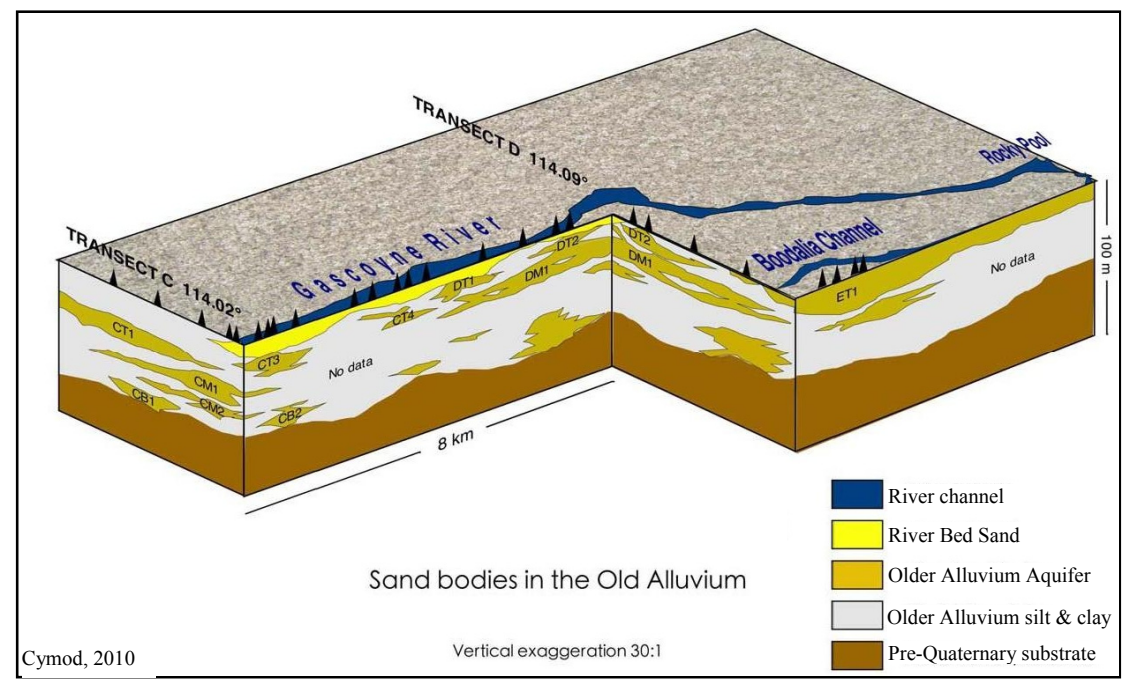

Figure 3: Conceptual cross section of the Gascoyne River alluvial sediments comprising Older Alluvium.

The saturated alluvial sediments of the Gascoyne River flood plain have been informally defined as Older Alluvium Aquifer (OAA) and River Bed Sand (RBS). The OAA ranges in thickness from approximately $20 \mathrm{~m}$ west of Rocky Pool to greater than $50 \mathrm{~m}$ near Carnarvon (Dodson [2]). Sediments comprising the OAA consist predominately of alternating and irregular, unconsolidated to semi-lithified, thin beds of poorly sorted sand, gravel and clay with varying sand and silt fractions (Martin [6]). The OAA is a heterogeneous and anisotropic aquifer system which is laterally not continuous having been deposited as channel lag or point-bar river channel sediment. The aquifer is unconfined to semi-confined depending upon its position within the Gascoyne River alluvium profile.

The RBS occupies the entire channel of the Gascoyne River where it occurs as the river bed load that is incised up to $5 \mathrm{~m}$ into the underlying OAA. This aquifer is composed predominately of angular to sub-angular quartz sand, with granitic and metasedimentary detritus rock, and angular secondary laterite, calcrete and silcrete (Dodson [2]). Grain size of the RBS varies from fine sand to cobbles. The thickness of the RBS varies from 1 to 12 metres with an average thickness of 3.5 metres. The RBS is recharged during river flow events, where saturation of this aquifer occurs soon after commencement of flow. The downward and lateral leakage of groundwater from the RBS recharges the underlying OAA and adjacent older alluvium within the river bank and flood 
plain. The RBS contains a finite amount of water which, in the vicinity of Carnarvon, is exhausted 6 to 9 months after a river flow (Allen [9]).

The "fresh" (<1000 mg/L TDS) groundwater resources are isolated to those alluvial sediments that have good connection to the surface water during river flow. The efficiency of recharge and quality of the groundwater within the OAA is directly controlled by the degree of connection that the aquifer has with the overlying RBS. Estimates of the groundwater storage with salinity less than 1000 $\mathrm{mg} / \mathrm{L}$ TDS within and adjacent to the CWR range between $100 \mathrm{GL}$ and $340 \mathrm{GL}$ $[6,9]$.

\section{Management areas and policies}

Expansion of the irrigated areas in Carnarvon in the 1950s through a period of below normal river flow resulted in the WA Government enacting control measures for the Gascoyne River alluvial aquifer system in 1959 Department of Northern Development [6]. The initial measures included establishment of the Carnarvon Irrigation District Advisory Committee (CIDAC) consisting of growers and representatives of the WA Public Works Department and Department of Agriculture. This was followed by the division of the Gascoyne River alluvial aquifer system from Rocky Pool to the river mouth into the 11 management Subareas A-L (excluding I), with Subarea A equating to the CHA and $\mathrm{B}-\mathrm{L}$ comprising the CWR.

Initially only extraction from the RBS was managed but in 1963 special legislation was enacted to extend control to wells and bores on private property through the issue of groundwater licences. Plantations were licensed for 36,000 or $72,000 \mathrm{~kL} / \mathrm{a}$ depending upon size, with up to $10000 \mathrm{~kL}$ available per month and a cease pumping condition when groundwater salinity exceeding $1,000 \mathrm{mg} / \mathrm{L}$ TDS. There are currently 156 groundwater licences in Subarea A (Figure 2), with a total licensed allocation of $8,300 \mathrm{GL} /$ year. Calculations of the sustainable groundwater allocation for both the RBS and OAA within Subarea A vary in accordance with the estimation of aquifer storage, groundwater quality and the statistical analysis of river flow events. Current estimates of the sustainable groundwater resource for Subarea A range between 5.8 and 6.1 ML. This is based upon the alluvial aquifer being able to supply the required volume of groundwater of a quality less than $1000 \mathrm{mg} / \mathrm{L}$ TDS in 8 out of 10 years (Cymod [7]).

Historically, the over-allocation of the groundwater resources was not a problem, as governance based upon local knowledge and experience was sufficient to maintain sustainability of the groundwater resource. Full licence allocation was never accessible due to cessation of pumping at $1000 \mathrm{mg} / \mathrm{L}$ TDS groundwater salinity. The WC is licensed to abstract $10.4 \mathrm{GL} / \mathrm{a}$ of groundwater from the CWR of which $1.8 \mathrm{GL} / \mathrm{a}$ is for town water supply. The GWC, through agreement with the $\mathrm{WC}$, distributes reticulated water from the $\mathrm{CWR}$ to plantations within the CHA. The location and development of economic bores within the CWR is a limiting factor with only 1 out of 10 drilled bores productive due to the discontinuous and anisotropic nature of the alluvial aquifer 
system. The GWC is evaluating the groundwater resources north of the Gascoyne River (Brickhouse Borefield) for an additional $4 \mathrm{GL} / \mathrm{a}$ (Crute and Nixon [10]).

The Gascoyne River alluvial aquifer is currently under stress. Aquifer stress is due to increased groundwater abstraction with expansion of the $\mathrm{CHA}$, greater duration between river flows considered to be the related to climate change, extension of growing season through the use of more varied crop varieties and changes in plantation ownership with expectations of full use of groundwater allocations.

Management of the Gascoyne River alluvial system utilises a combination of policies developed to take into consideration historical data and stakeholder knowledge. These policies include:

- Metering and limiting abstraction to the determined sustainable yield;

- Imposing a maximum monthly limit on groundwater production during periods of 'no river flow' to protect groundwater supply and quality;

- Maintaining a maximum groundwater salinity threshold of $1000 \mathrm{mg} / \mathrm{L}$ TDS to minimise the risk of lateral movement of saline groundwater from bank storage and the landward movement of the salt water interface at the mouth of the river;

- Allowing 'unrestrictive pumping during river flow events; and

- Limiting water trading due to the variability in the aquifer system.

\section{Groundwater management tools}

A number of management tools have been used to regulate groundwater abstraction from the Gascoyne River alluvial aquifer system. The earliest tool comprised the use of anecdotal community knowledge together with individual plantation experience to maintain private supplies of groundwater with salinity less than $1000 \mathrm{mg} / \mathrm{L}$ TDS. Plantation owners developed groundwater resources according to local knowledge and historic experience, generally without reference to accurate estimations of aquifer capacity or potential long term impacts. Aquifer stress following several extended priors of no flow in the 1950s led to the commencement of WA Government management. Continued degradation of the aquifer in the 1960s, through a period of adequate river flows, marked the start of WA Government evaluations and hydrogeological studies. These studies, together with regular groundwater monitoring, provided the data needed to develop groundwater models for assessing the status of the aquifer system and modifying groundwater abstraction policies.

The earliest model developed to assess the status of the Gascoyne River alluvial aquifer system was designed by the Public Works Department of WA in 1980 (Ventriss [11]). This system was a distributed parameter numerical model running on a mainframe UNIVAC computer. In the early 1990 s the UNIVAC model outputs were incorporated into a spreadsheet tool referred to as CIDAC after the Carnarvon Irrigation District Allocation Committee. CIDAC aquifer 
status calculations were based upon "full" groundwater storage for the CHA and CWR estimated as 19.4 GL for the RBS and a 0.00 "Depletion Volume" in the semi confined OAA. The model used groundwater level measurement from a selected set of observation bores with pre-calculated 'lookup' tables to provide a rapid and uniform means of assessing aquifer storage. CIDAC continues to be utilised to provide a uniform method for the estimation of aquifer status for the Gascoyne River alluvial aquifer system. Reports generated by CIDAC date back to May 1997. Data prior to this date were lost due to corruption of the application. Current aquifer status reporting incorporates groundwater salinity modelling of the CHA (Subarea A).

The WA Government funded the development of a groundwater model in 2000 that utilised the United States Geological Survey three dimensional, finite difference, modular groundwater flow model (MODFLOW). The groundwater model was referred to as the Gascoyne River Floodplain Aquifer Model or GRFAMOD. GRFAMOD was constructed as a numerical model of the Gascoyne River groundwater flow system that simulated transient historical groundwater flow events. This was accomplished for the for the entire length of the public and private abstraction area of the Gascoyne River from Rocky Pool to the river mouth through division of the area into $100 \times 100 \mathrm{~m}^{2}$ finite difference grids (Dodson [2]). GRFAMOD outputs indicated that the groundwater system was capable of supplying $18 \mathrm{GL} / \mathrm{a}$ over two years of 'no flow'. The model was not capable of incorporating solute flow and could not predict groundwater quality changes arising from groundwater abstraction over an extended period of 'no flow'. This limitation restricted the use of the model's outputs as management policy required maintaining groundwater quality to less than 1000 $\mathrm{mg} / \mathrm{L}$ TDS. A precautionary approach was adopted and the existing $12.4 \mathrm{GL} / \mathrm{a}$ allocation limit was maintained (Dodson [2]).

The WA Department of Water, in 2009, contracted the construction of a new groundwater model, GASFAMS (GAScoyne River Floodplain Aquifers Modelling System) over the Gascoyne River alluvial system. GASFAMS was developed using MODFLOW 2000 and the MT3DMS solute module together with Visual MODFLOW 2009 as the graphic user interface. The Gascoyne River alluvial aquifer system was portrayed in GASFAMS as 10 layers with Layers 1-3 depicting the RBS and 7-10 describing the OAA (Cymod [7]).

GASFAMS offered a number of improvements over the earlier GRFAMOD. The foremost of these improvements was the ability to track groundwater salt increase and movement related to aquifer dewatering. The combination of improved programming with more powerful PC systems decreased scenario runs times from over 8 hours to less than 30 minutes. This allowed the development of multiple river flow and abstraction scenarios (Table 1) to provide a predictive tool for groundwater management. Scenarios run considered both normal and drought (extended 'no flow' cycles) conditions. A maximum abstraction of 5.6 GL/a (Subarea A) and 22.8 GL/a (Subarea B-L) was indicated for "drought" conditions if additional abstraction from the Brickhouse Borefield was available. 
Table 1: Climate Scenarios and predicted sustainable allocation.

\begin{tabular}{|c|c|c|c|c|c|}
\hline \multirow[b]{2}{*}{ Scenario } & \multirow[b]{2}{*}{ Description } & \multirow{2}{*}{$\begin{array}{l}\text { Recharge } \\
\text { Sequence }\end{array}$} & \multicolumn{3}{|c|}{ Allocation Components (GL/annum) } \\
\hline & & & Area A & Area B-L & Total \\
\hline 1 & Base Case & $\begin{array}{c}\text { Normal } \\
1991-1999\end{array}$ & 5.8 & 12.2 & 18.0 \\
\hline 2 & No Flow & $\begin{array}{c}\text { Drought } \\
2000-2008 \\
\text { Salinity } A> \\
1000 \mathrm{mg} / \mathrm{L} \\
\end{array}$ & 0.0 & 18.0 & 18.0 \\
\hline 3 & $\begin{array}{c}\text { Areas } A-L \text { Best } \\
\text { Case }\end{array}$ & Normal & 5.8 & $>12.2$ & $>18.0$ \\
\hline 4 & $\begin{array}{c}\text { Areas A-L Best } \\
\text { Case }\end{array}$ & $\begin{array}{c}\text { Drought } \\
2000-2008 \\
\text { Salinity } A> \\
1000 \mathrm{mg} / \mathrm{L}\end{array}$ & $0-5.8$ & $>18$ & $>18.0$ \\
\hline 5 & $\begin{array}{c}\text { Brickhouse } \\
\text { Borefield } 4 \mathrm{GL} / \mathrm{a}\end{array}$ & Normal & 5.8 & $>12.2+4$ & $>22.0$ \\
\hline 6 & $\begin{array}{c}\text { Brickhouse } \\
\text { Borefield } 4 \text { GL/a }\end{array}$ & $\begin{array}{c}\text { Drought } \\
\text { 2000-2008 } \\
\text { Salinity } A> \\
1000 \mathrm{mg} / \mathrm{L}\end{array}$ & $0-5.8$ & $>18+4$ & $>22.0$ \\
\hline
\end{tabular}

\section{Conclusion}

The Gascoyne River alluvial flood plain contains a complex and non-uniform aquifer system comprising both current riverbed sand (RBS) and palaeosediments (OAA). The groundwater within the alluvial aquifer supports the CHA where maintenance of water quantity and quality is essential to sustain current markets and growth envisioned under the Gascoyne Foodbowl Initiative (Aha! [12]). There are competing water interests across the CHA comprising varying groundwater conditions, crop requirements and commercial values. Local knowledge of the groundwater system is diminishing. It is difficult to maintain excess groundwater storage through normal years to ensure water availability through the periods of no flow. Aquifer monitoring and accurate data assessment is essential to make confident predictions that provide water security to the CHA.

\section{Reference}

[1] Hill, T., Growing bananas in Carnarvon, Information and Media Services, Western Australia Department of Agricultural, Carnarvon, pg.5, 1993.

[2] Dodson, W. J., Groundwater recharge from the Gascoyne River, Western Australia, Hydrogeological record series HG 32, Western Australia Department of Water, Perth, pp. 3-128, 2009.

[3] Department of Northern Development (DND), Carnarvon and Gascoyne groundwater supply scheme, Western Australia, Commonwealth of Australia, Canberra, pp. 17-19, 1972. 
[4] Public Works Department, Water supply of Carnarvon and the Gascoyne Irrigation Area , An Environmental Impact Study, Western Australia Public Works Department, Perth, pp. 3-4, September 1973.

[5] Gascoyne Development Commission, Gascoyne Horticulture Investment Profile, Government of Western Australia, Perth, pp. 2-4, 2010.

[6] Martin, M.W., Groundwater resources of the Older Alluvium, Gascoyne River, Carnarvon, Western Australia, Western Australia Geological Survey Hydrogeology Report, 1990/21, pp. 3-20, 1990.

[7] CyMod Systems Pty Ltd, The Development of the Gascoyne River Floodplain Aquifers Modelling System, GASFAMS V1, Western Australia Department of Water, Perth, pp. 1-133, September 2009.

[8] Rockwater, The separation of fresh groundwater resources along the Gascoyne River by the Rocky Pool anticline, Western Australia Water Corporation, Perth, pp. 7-9, January 2001.

[9] Allen, A.D., Results of Investigation into groundwater resources along the Lower Gascoyne River for Carnarvon irrigation and Town water supplies, Geological Survey of Western Australia Record 1972/9, Perth, pg. 7, 1972.

[10] Crute J. and Nixon, R., Gascoyne River Alluvium - Brickhouse Station, Groundwater Modelling for Government of Western Australia (DAFWA and DoW), Global Groundwater, Perth, pg. 17, February 2008.

[11] Ventriss, H.B., Gascoyne River Groundwater Scheme Yield Study, Water Resources Technical Report No. 91, Water Resources Section, Public Works Department of Western Australia, Perth, pp. 3-24, November 1980.

[12] Aha! Consulting, Workshop notes $23^{\text {rd }}$ and $24^{\text {th }}$ February 2010, Gascoyne Foodbowl Local Consultative Committee, Perth, pp. 1-25, March 2010. 